\title{
High-Amylose Resistant Starch Increases Hormones and Improves Structure and Function of the Gastrointestinal Tract: A Microarray Study
}

\author{
Michael J. Keenan ${ }^{a}$ Roy J. Martin ${ }^{a, b}$ Anne M. Raggio ${ }^{a}$ \\ Kathleen L. McCutcheon ${ }^{a}$ Ian L. Brown ${ }^{f} \quad$ Anne Birkett $^{c}$ \\ Susan S. Newman ${ }^{b}$ Jihad Skaf ${ }^{d}$ Maren Hegsted ${ }^{a}$ Richard T. Tulley ${ }^{a}$ \\ Eric Blair ${ }^{d}$ June Zhou ${ }^{\mathrm{e}}$ \\ ${ }^{a}$ Louisiana State University Agricultural Center, and bennington Biomedical Research \\ Center, Baton Rouge, La., 'Corn Products International, Chicago, III., ' Life Technologies, \\ Carlsbad, Calif., and ' Laboratory of Geriatric Endocrinology and Metabolism, Veterans \\ Affairs Medical Center, Washington, D.C., USA; ${ }^{f}$ Clover Corporation, Gymea, N.S.W., Australia
}

\section{Key Words}

High-amylose maize - Resistant starch - Microarray - Validation - Cecal cells •

Gastrointestinal tract

\begin{abstract}
Background/Aims: Type 2 resistant starch from high-amylose maize (HAM-RS2) is associated with increased fermentation, increased expression of proglucagon (gene for GLP-1) and peptide YY (PYY) genes in the large intestine, and improved health. To determine what other genes are up- or downregulated with feeding of HAM-RS2, a microarray was performed. Methods: Adult, male Sprague Dawley rats were fed one of the following three diets for a 4-week study period: cornstarch control (CC, $3.74 \mathrm{kcal} / \mathrm{g})$, dietary energy density control (EC, $3.27 \mathrm{kcal} / \mathrm{g})$, and $30 \%$ HAM-RS2 (RS, $3.27 \mathrm{kcal} / \mathrm{g}$ ). Rat microarray with $\sim 27,000$ genes and validation of 94 representative genes with multiple qPCR were used to determine gene expression in total RNA extracts of cecal cells from rats. The RS versus EC comparison tested effects of fermentation as energy density of the diet was controlled. Results: For the RS versus EC comparison, $86 \%$ of the genes were validated from the microarray and the expression indicates promotion of cell growth, proliferation, differentiation, and apoptosis. Gut hormones GLP-1 and PYY were increased. Conclusions: Gene expression results predict improved structure and function of the Gl tract. Production of gut hormones may promote healthy functions beyond the Gl tract.
\end{abstract}




\section{Introduction}

Although the mechanism remains unclear, dietary resistant starches (RS) have been shown to decrease plasma cholesterol and triglycerides, increase insulin sensitivity, decrease fat storage, and produce anticancer effects in humans [1-13]. The current research is to gather gene expression data that will help identify mechanisms by which RS improve health. RS are one type of non-digestible, fermentable fiber. Generally, RS are categorized into 4 categories [14]: RS1 is a result of the structured food matrix in unprocessed whole grains, seeds or legumes; RS2 is generally high in amylose, but is primarily the result of an organized granular structure tightly packed in a radial pattern as in high-amylose cornstarch products; RS3 is retrograded starch as in cooked and then cooled potatoes, and RS4 is considered chemically modified starch with either constituent groups attached or linkages between starch molecules.

RS will potentially have three major effects when included in the diet: (1) dilution of dietary energy as the metabolizable energy of one type of RS2, HAM-RS2, is $2.8 \mathrm{kcal} / \mathrm{g} \mathrm{com}$ pared to the 3.6-4 kcal/g of typical starches [10], (2) a bulking effect similar to non-fermentable fiber, and (3) fermentation to short-chain fatty acids and an increase in expression of genes in the gut and peptide hormones in plasma $[5,8,9,11,12]$.

RS is fermented to short-chain fatty acids by microflora in the large intestine [5, 8]. The colonic fermentation of one specific form of RS from high-amylose maize, HAM-RS2, has been shown to elicit several beneficial changes such as increased cecal and large intestine gene expression of peptide YY (PYY) and proglucagon (gene for GLP-1), increased plasma levels of PYY and glucagon-like peptide-1 (GLP-1) and decreased abdominal fat $[5,8,9]$. Thus, it is important to understand the full scale of gene expression changes by HAM-RS2 in the cecum, where the fermentation occurs. However, our previous studies have been limited to a handful of genes using real-time reverse transcriptase-polymerase chain reaction (qPCR) and peptide hormone assays. The current study is a microarray with $\sim 27,000$ genes of the rat genome followed by a validation or focusing of the microarray that was performed on 94 genes. We compared gene expression profiles in cecal cells of rats fed a HAM-RS2 diet with that of rats fed two types of control diets: one was a standard AIN-93G diet with added cornstarch ( $\mathrm{CC}=$ cornstarch control), which is greater in metabolizable energy than the RS diet [15]; the second one had a metabolizable energy density equal to the RS diet due to the addition of cellulose (EC = energy density control). The inclusion of the EC diet allowed for testing of fermentation effects separately from energy density differences.

\section{Methods}

Animals and Diets

Forty-five 8-week-old male Sprague Dawley rats (Harlan, Indianapolis, Ind., USA) were fed treatment diets for 4 weeks: a rapidly digestible cornstarch control (CC, $3.74 \mathrm{kcal} / \mathrm{g}$ ), an energy control with a rapidly digestible cornstarch and purified, non-fermentable cellulose added to dilute metabolizable energy (EC, $3.27 \mathrm{kcal} / \mathrm{g}$ ), and the resistant starch treatment (RS, $3.27 \mathrm{kcal} / \mathrm{g}$ ) using a fermentable, high-amylose cornstarch resistant starch type 2, HAM-RS2 (table 1). The number of rats in each treatment group was 15 , purchased in three separate orders from Harlan Co., i.e. $n=5 /$ shipping for each of the three treatment groups. Note that the staggering of orders equalized for the three treatments was done to control for condition of rats at different shipping times.

The EC and RS diets had equal energy density. Energy content of the starches was calculated based on an approximate metabolizable energy content of $2.8 \mathrm{kcal} / \mathrm{g}$ for the high-amylose cornstarch $[10,16]$ and using the Atwater factor of $4.0 \mathrm{kcal} / \mathrm{g}$ for the rapidly digestible cornstarch $(4.0 \mathrm{kcal} / \mathrm{g})$. A modified version of the Englyst method [17] was used to derive an estimate of 56\% resistant starch for the HAM-RS2. Thus, the HAM-RS2 diet had $530.7 \mathrm{~g}$ of Hi-maize ${ }^{\circledR}$ starch and $297 \mathrm{~g}$ of resistant starch, or $29.7 \%$ of the weight of the diet (table 1). 


\section{Nutrigenetics Nutrigenomics}

Table 1. Composition of the rat diets

\begin{tabular}{l|l}
\hline J Nutrigenet Nutrigenomics 2012;5:26-44 \\
\hline DOI: 10.1159/000335319 & $\begin{array}{l}\text { @ 2012 S. Karger AG, Basel } \\
\text { www.karger.com/jnn }\end{array}$ \\
Published online: April 20, 2012 &
\end{tabular}

Keenan et al.: Microarray and High-Amylose Maize Resistant Starch

\begin{tabular}{llll}
\hline Ingredient & CC & EC & RS \\
\hline Casein, g & 200 & 200 & 200 \\
Sucrose, g & 100 & 100 & 100 \\
Cornstarch, ga & 530.69 & 403.69 & 0 \\
Resistant cornstarch, gb & 0 & 0 & 530.69 \\
Cellulose, g & 50 & 177 & 50 \\
Soybean oil, g & 70 & 70 & 70 \\
Mineral Mix (AIN-93M), g & 35 & 35 & 35 \\
Vitamin Mix (AIN-93), g & 10 & 10 & 10 \\
Choline chloride, g & 1.3 & 1.3 & 1.3 \\
L-Cystine, g & 3 & 3 & 3 \\
BHT, g & 0.014 & 0.014 & 0.014 \\
Total weight, g & 1,000 & 1,000 & 1,000 \\
Energy density, kcal/gc & 3.74 & 3.27 & 3.27 \\
\hline
\end{tabular}

BHT = Butylated hydroxytoluene.

${ }^{a} 100 \%$ amylopectin cornstarch (Amioca ${ }^{\circledR}$; National Starch LLC, Bridgewater, N.J., USA). ${ }^{\mathrm{b}}$ High-amylose maize cornstarch (Himaize ${ }^{\circledR} 260$; National Starch LLC). This product has RS2 and is described in the methods section of the text.

Rats were sacrificed by heart puncture and plasma was collected for analysis of PYY and GLP-1 by radioimmunoassay (Phoenix, Burlingame, Calif., USA) and ELISA (Millipore, Billerica, Mass., USA), respectively. The full ceca were excised and weighed, and an aliquot of cecal contents was removed for measurement of $\mathrm{pH}$. In addition, three abdominal fat pads, retroperitoneal, perirenal and epididymal, were also removed and weighed. After cecal contents were removed, the cecum was carefully opened with scissors and the inner surface of the cecum was rinsed with sterilized saline three times. Cecal cell samples used for RNA extraction were collected by gently scraping the inner cecal surface. This layer of cells includes epithelial cells (colonocytes), nerve cells, endocrine cells and immune cells, which represent all cell types that would be exposed to short-chain fatty acids, the fermentation products of RS in the cecum. Previously, Chen et al. [18] used a similar approach for collecting cells of the proximal colon for a gene array with dietary fibers.

\section{RNA and cDNA}

RNA was isolated from cecum cell scrapings using the Qiagen RNeasy mini kit (Valencia, Calif., USA) with an additional on-column DNase digestion. RNA samples were eluted with RNase-free water. RNA concentrations and integrities were determined using an Agilent Bioanalyzer (Foster City, Calif., USA). Only RNA samples with a concentration over $2.3 \mathrm{ng} / \mu \mathrm{l}$ and an RNA integrity number greater than 8.0 were used. The best total RNA samples from each time period (see 'Animals and Diets' section above) were used (maximum of three except for one time period with $n=4$ for RS). Thus, the total $n$ for the three groups was: RS $n=10$, and CC and EC $n=9$. The Applied Biosystems Chemiluminescent RT Labeling Kit (Carlsbad, Calif., USA) was used to produce digoxigenin-labeled cDNA for hybridization to the microarray.

\section{Microarray Procedure}

We used the Applied Biosystems rat genomic chips ( 27,000 genes). From each sample, $10 \mu \mathrm{g}$ of labeled cDNA was hybridized to a microarray and processed for scanning using the Applied Biosystems Chemiluminescent Detection Kit. Microarrays were scanned by an Applied Biosystems 1700. ABarray software (Bioconductor.org) was used to quantile normalize the signal across all arrays. It filtered the data to retain genes having a signal-to-noise ratio $\geq 3$. The data were also filtered to remove data derived from array spots which were flagged as defective by the AB1700 software. Fold change (FC), $\log _{2}$ FC, p value, Benjamini-Hochberg adjusted $\mathrm{p}$ value, and FC bin were provided for each detected gene or transcript. 
Table 2. Microarray results

\begin{tabular}{lccc}
\hline Results & CC vs. EC & CC vs. RS & RS vs. EC \\
\hline 'Present' gene expression $(\mathrm{S} / \mathrm{N} \geq 3)$ & 10,023 & 10,573 & 10,388 \\
Gene differences $\mathrm{p}<0.05$ & 629 & 3,192 & 2,640 \\
Gene differences $\mathrm{p}<0.01$ & 158 & 1,769 & 1,301 \\
PANTHER gene pathways $\mathrm{p}<0.05^{\mathrm{a}}$ & 18 & 23 & 17 \\
Unclassified genes $\mathrm{p}<0.05^{\mathrm{b}}$ & 515 & 2,711 & 2,266 \\
\hline
\end{tabular}

$\mathrm{S} / \mathrm{N}=$ Signal-to-noise ratio.

a PANTHER was the gene ontology software program used to estimate the number of gene mRNAs in pathways or unclassified. ${ }^{b}$ www.pantherdb.org.

Three gene lists from ABarray pairwise comparisons CC-EC, CC-RS, and EC-RS were generated. The Protein Analysis through Evolutionary Relationships (PANTHER, www.pantherdb.org) software was used to determine if significantly affected genes were known to be assigned to a biochemical pathway or were unclassified at the present time. Analysis was performed with and without Bonferroni adjustment to determine statistical significance of pathway gene hits. In addition, the software was used to determine if molecular functions of the unclassified genes were known. Additionally, Spotfire ${ }^{\circledR}$ software (TIBCO, Somerville, Mass., USA) was used for hierarchical clustering.

\section{Validation Procedure}

We used Applied Biosystems 384-well TaqMan ${ }^{\circledR}$ Custom Arrays for qPCR to focus on and confirm 94 genes from the microarray results. The 96a format was chosen, which includes one mandatory control, 18SrRNA, and allows four samples per 384-well array. Another control, cyclophilin F, was also included. The total $\mathrm{n}$ for the three groups was: RS and $\mathrm{EC} \mathrm{n}=8$ and $\mathrm{CC} n=7$, and each of these biological samples were run in triplicate. The RS versus EC comparison was considered the most important of the three comparisons as it represents the effect of resistant starch beyond simple energy dilution of the diet. Narrowing our list to 94 genes was accomplished by choosing genes with the greatest FCs and with the lowest $\mathrm{p}$ values. Only genes that were inventoried by Applied Biosystems could be included in the custom arrays. Additionally, neurotensin, a peptide hormone with a high FC and very low $\mathrm{p}$ value, was run separately from the custom arrays. The 18S rRNA gene was used as the reference gene in analyses as it was more consistently expressed than cyclophilin F from sample to sample and between experimental groups. The custom array data were normalized using $18 \mathrm{~S}$ followed by FC calculation using the $\Delta \Delta \mathrm{CT}$ method $\left(2^{-\Delta \Delta \mathrm{Ct})}\right.$ [19]. These values were submitted to ABqPCR software to determine $p$ values using $t$ tests for comparisons of CC-EC, CC-RS, and EC-RS. The average values for each gene in each group were used to determine FCs.

\section{Results}

\section{Microarray}

Over 10,000 genes were considered 'present' (the signal-to-noise ratio was $\geq 3$ ) for all three comparisons. The RS versus CC comparison had the greatest number of differences in mRNA expression for genes out of the possible $\sim 27,000$ genes measured on the microarrays. The greater number of differentially expressed genes for RS versus CC appears logical as this comparison represents the greatest dietary differences that include dilution of dietary energy density and fermentation with the addition of HAM-RS2 to the diet. A summary of the microarray results is shown in table 2 . Strong global differences among the three groups are depicted in a hierarchical cluster using $\mathrm{Z}$ scores from signal intensities of genes that had significantly different FC at $\mathrm{p}<0.01$ (fig. 1). 


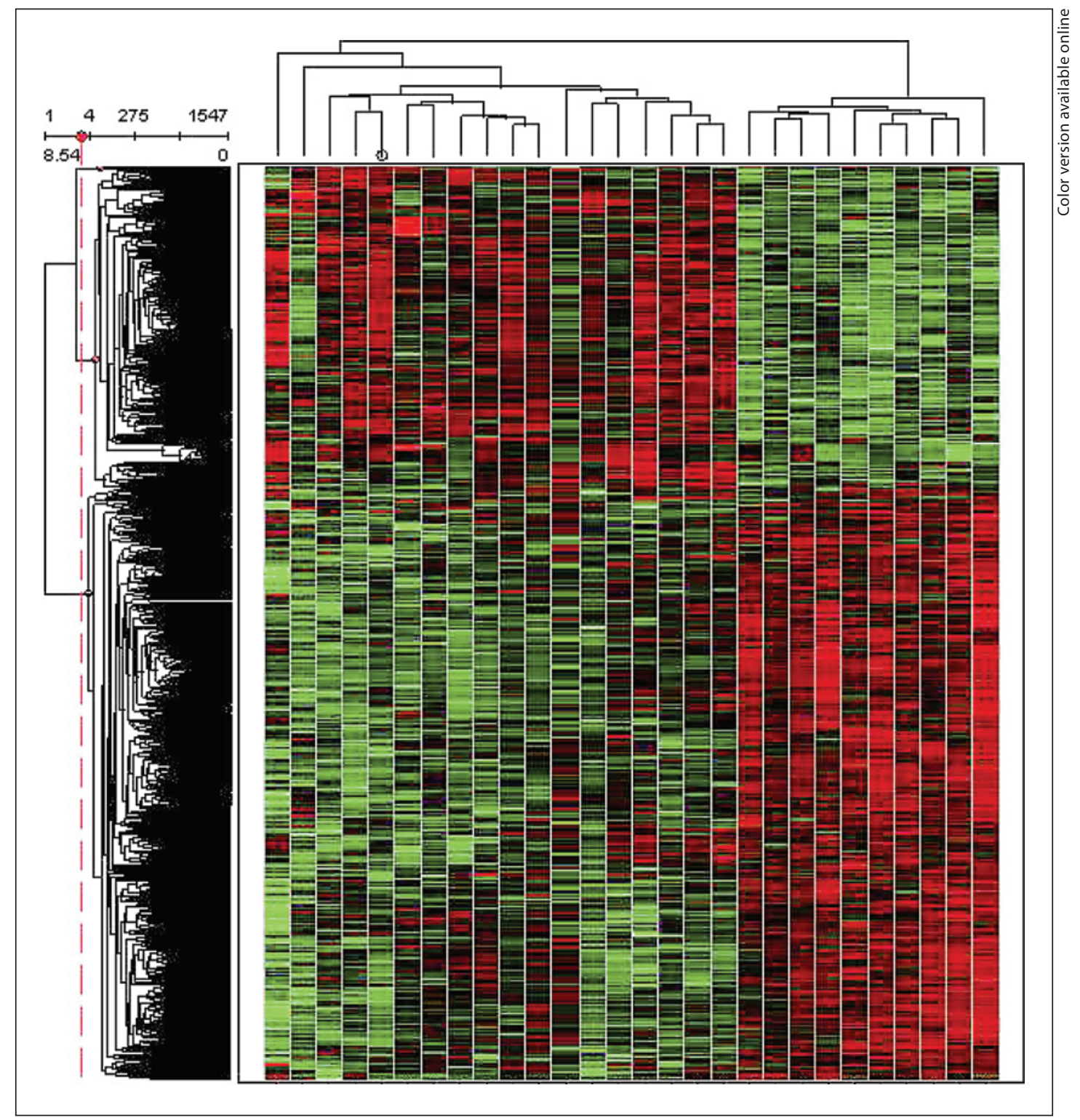

Fig. 1. Hierarchical cluster of the $\mathrm{Z}$ scores of the microarray signals for RS, CC and EC groups for genes that were significantly different at $\mathrm{p}<0.01$. This visualization shows data in a dendrogram (a tree graph) based on the similarity between treatment replicates. The $\mathrm{Z}$ scores were determined by calculating the three groups' combined mean for each gene, and then individual differences of treatment replicates from the mean were divided by the standard deviation. This is one type of normalization for making gene-gene comparisons. Different genes are shown in each separate row. The columns are individual replicates of treatments and from left to right they are: EC3; CC3; CC14; CC2; CC8; CC12; CC4; CC15, EC15, EC13; EC12; EC6; CC7; EC5, EC2; CC6; EC9; EC7; RS3; RS9; RS15, RS8; RS13; RS4; RS12; RS14; RS7; RS5.

\section{Validation}

The genes chosen from the microarray for validation have their microarray results listed in table 3 with names, abbreviations, FCs, p values, category of function (pathway or unclassified), and NCBI Gene ID number. PANTHER gene expression analysis without the Bonferroni adjustment for the RS versus EC comparison demonstrated that our microarray gene 


\section{Nutrigenetics Nutrigenomics}

\begin{tabular}{l|l}
\hline J Nutrigenet Nutrigenomics 2012;5:26-44 \\
\hline $\begin{array}{l}\text { DOI: 10.1159/000335319 } \\
\text { Published online: April 20, 2012 }\end{array}$ & $\begin{array}{l}\text { @ 2012 S. Karger AG, Basel } \\
\text { www.karger.com/jnn }\end{array}$ \\
\hline
\end{tabular}

Keenan et al.: Microarray and High-Amylose Maize Resistant Starch

Table 3. List of genes from microarray with RS versus EC results and used in validation (alphabetical by abbreviation)

\begin{tabular}{|c|c|c|c|c|c|}
\hline Name & $\begin{array}{l}\text { Abbrevi- } \\
\text { ation }\end{array}$ & $\begin{array}{l}\text { NCBI gene } \\
\text { ID }\end{array}$ & $\mathrm{FC}$ & $\mathrm{p}$ value & Function (pathway or unclassified) \\
\hline Acetyl-coenzyme A acyltransferase 3 & Acat 3 & 308100 & 1.61 & 0.000 & Unclassified \\
\hline Actinin alpha 1 & Actn1 & 81634 & 1.98 & 0.000 & Integrin \\
\hline Actinin alpha 4 & Actn 4 & 63836 & 1.97 & 0.000 & Integrin \\
\hline Adrenomedullin & Adm & 25026 & 5.32 & 0.000 & Unclassified \\
\hline Aldehyde oxidase 3 & Aox3 & 493909 & 0.56 & 0.004 & Adenine and hypoxanthine salvage \\
\hline Adaptor protein complex AP-2 & Ap2a2 & 81637 & 1.51 & 0.004 & Huntington disease \\
\hline Amphiregulin & Areg & 29183 & 25.64 & 0.000 & EGF receptor signaling \\
\hline ADP-ribosylation factor 2 & Arf2 & 79119 & 1.51 & 0.006 & Huntington disease + integrin \\
\hline ADP-ribosylation factor 3 & Arf3 & 140940 & 1.78 & 0.002 & Huntington disease + integrin \\
\hline Rho GTPase activating protein 27 & Arhgap27 & 303583 & 1.45 & 0.002 & PDGF signaling \\
\hline Rho GTPase activating protein 8 & Arhgap8 & 300115 & 2.15 & 0.002 & $\begin{array}{l}\text { Angiogenesis + PDGF signaling + VEGF } \\
\text { signaling + cytoskeleton regulation by } \\
\text { RhoGTPase }\end{array}$ \\
\hline Asparagine synthetase & Asns & 25612 & 2.73 & 0.000 & Asparagine and aspartate biosynthesis \\
\hline Activating transcription factor 3 & Atf3 & 25389 & 3.26 & 0.000 & Apoptosis \\
\hline Beta-site APP-cleaving enzyme 2 & Bace2 & 288227 & 0.5 & 0.004 & Alzheimer disease-amyloid secretase \\
\hline Bone morphogenetic protein 2 & Bmp2 & 29373 & 1.31 & 0.009 & TGF-beta signaling \\
\hline Bone morphogenetic protein 3 & Bmp3 & 25667 & 2.48 & 0.030 & Unclassified \\
\hline $\begin{array}{l}\text { Calcium channel, voltage-dependent, } \mathrm{T} \text { type, } \\
\text { alpha } 1 \mathrm{H} \text { subunit }\end{array}$ & Cacnalh & 114862 & 3.12 & 0.005 & Unclassified \\
\hline Caspase 4 & Casp4 & 114555 & 1.59 & 0.000 & Unclassified \\
\hline Cystathionine beta synthase & Cbs & 24250 & 1.52 & 0.008 & Cysteine biosynthesis \\
\hline CD14 antigen & $\mathrm{Cd} 14$ & 60350 & 0.56 & 0.005 & Toll-like receptor \\
\hline Cyclin-dependent kinase & $\mathrm{Cdk} 2$ & 362817 & 1.59 & 0.006 & p53 + p53 feedback loops 2 \\
\hline Cyclin-dependent kinase inhibitor $1 \mathrm{~A}$ & Cdkn1a & 114851 & 2.18 & 0.000 & Interleukin + p53 feedback loops $2+$ p53 \\
\hline Chromogranin A & Chga & 24258 & 0.52 & 0.000 & Unclassified \\
\hline Chromogranin B & Chgb & 24259 & 0.54 & 0.000 & Unclassified \\
\hline Collagen, type 5, alpha 3 & Col5a3 & 60379 & 2.72 & 0.003 & Integrin \\
\hline Dual specificity phosphatase 1 & Dusp1 & 114856 & 5.99 & 0.000 & Unclassified \\
\hline Dual specificity phosphatase 4 & Dusp4 & 60587 & 2.96 & 0.000 & Oxidative stress response \\
\hline Dual specificity phosphatase 5 & Dusp5 & 171109 & 1.65 & 0.001 & Oxidative stress response \\
\hline Dual specificity phosphatase 6 & Dusp6 & 116663 & 1.68 & 0.001 & Oxidative stress response \\
\hline Eukaryotic translation initiation factor 2 , subunit 1 & Eif2s1 & 54318 & 1.42 & 0.004 & Apoptosis \\
\hline Enolase 1, alpha & Eno1 & 24333 & 1.59 & 0.000 & Glycolysis \\
\hline Epiregulin & Ereg & 59325 & 7.81 & 0.000 & EGF receptor signaling \\
\hline Fatty acid binding protein 2 & Fabp2 & 25598 & 4.55 & 0.000 & Unclassified \\
\hline Fatty acid binding protein 6 , ileal (gastrotropin) & Fabp6 & 25440 & 0.12 & 0.012 & Unclassified \\
\hline Farnesyl diphosphate farnesyl transferase 1 & Fdft1 & 29580 & 1.55 & 0.008 & Cholesterol biosynthesis \\
\hline Fibroblast growth factor receptor 2 & Fgfr2 & 25022 & 0.56 & 0.000 & Angiogenesis \\
\hline Fibronectin 1 & Fn1 & 25661 & 2.28 & 0.027 & Integrin \\
\hline Fyn-related kinase & Frk & 79209 & 1.57 & 0.000 & $\begin{array}{l}\text { B-cell activation }+ \text { integrin }+ \\
\text { axon guidance }\end{array}$ \\
\hline Growth arrest and DNA-damage-inducible 45 alpha & Gadd45a & 25112 & 2.70 & 0.000 & p53 +PI3kinase \\
\hline Growth arrest and DNA-damage-inducible 45 beta & Gadd45b & 299626 & 2.12 & 0.014 & p53 \\
\hline Growth arrest specific 6 & Gas6 & 58935 & 0.58 & 0.005 & Unclassified \\
\hline Glucagon & Gcg & 24952 & 6.9 & 0.001 & Unclassified \\
\hline Growth differentiation factor 15 & Gdf15 & 29455 & 2.97 & 0.007 & Unclassified \\
\hline Ghrelin precursor & Ghrl & 59301 & 0.66 & 0.014 & Unclassified \\
\hline Glutamate oxaloacetate transaminase 2 & Got2 & 25721 & 1.56 & 0.001 & Asparagine and aspartate biosynthesis \\
\hline Glycogen synthase kinase 3 alpha & Gsk3a & 50686 & 1.89 & 0.001 & $\begin{array}{l}\text { Insulin IGF PKB +angiogenesis + } \\
\text { interleukin + PI3Kinase + hedgehog } \\
\text { signaling }\end{array}$ \\
\hline Glutathione S-transferase Yc2 subunit & Gsta5 & 494500 & 10.6 & 0.000 & Unclassified \\
\hline Guanylate cyclase activator $2 \mathrm{~b}$ & Guca2b & 64055 & 1.51 & 0.008 & Unclassified \\
\hline Hemopoietic cell kinase & Hck & 25734 & 0.58 & 0.001 & $\begin{array}{l}\text { Parkinson disease }+ \text { angiogenesis }+ \\
\text { integrin }+ \text { interleukin }\end{array}$ \\
\hline Hairy and enhancer of split 1 (Drosophila) & Hes1 & 29577 & 1.44 & 0.003 & Notch signaling \\
\hline Hypoxia inducible factor 1, alpha subunit & Hifla & 29560 & 1.59 & 0.000 & Angiogenesis \\
\hline $\begin{array}{l}\text { Heat shock } 70 \text { kDa protein } 5 \\
\quad \text { (glucose-regulated protein) }\end{array}$ & Hspa5 & 25617 & 1.63 & 0.000 & Parkinson disease \\
\hline
\end{tabular}




\section{Nutrigenetics Nutrigenomics}

\begin{tabular}{l|l}
\hline J Nutrigenet Nutrigenomics 2012;5:26-44 \\
\hline $\begin{array}{l}\text { DOI: 10.1159/000335319 } \\
\text { Published online: April 20, 2012 }\end{array}$ & $\begin{array}{l}\text { @ 2012 S. Karger AG, Basel } \\
\text { www.karger.com/jnn }\end{array}$ \\
\hline
\end{tabular}

Table 3 (continued)

\begin{tabular}{|c|c|c|c|c|c|}
\hline Name & $\begin{array}{l}\text { Abbrevi- } \\
\text { ation }\end{array}$ & $\begin{array}{l}\text { NCBI gene } \\
\text { ID }\end{array}$ & FC & $\mathrm{p}$ value & Function (pathway or unclassified) \\
\hline Isocitrate dehydrogenase $2(\mathrm{NADP}+)$ & $\operatorname{Idh} 2$ & 361596 & 1.52 & 0.003 & Tricarboxylic acid \\
\hline Isopentenyl-diphosphate delta isomerase & Idi1 & 89784 & 2.23 & 0.000 & Cholesterol biosynthesis \\
\hline Interleukin 15 & Il15 & 25670 & 0.69 & 0.006 & Interleukin \\
\hline Interleukin 1 alpha & Illa & 24493 & 5.03 & 0.000 & Interleukin \\
\hline Intersectin 1 & Itsn1 & 29491 & 2.06 & 0.008 & Unclassified \\
\hline Jun-B oncogene & Junb & 24517 & 2.38 & 0.000 & TGF-beta \\
\hline Leukotriene A4 hydrolase & Lta $4 \mathrm{~h}$ & 299732 & 1.5 & 0.000 & Unclassified \\
\hline Leukotriene $\mathrm{C} 4$ synthase & Ltc4s & 114097 & 0.57 & 0.000 & $\begin{array}{l}\text { Inflammation-mediated chemokine and } \\
\text { cytokine }\end{array}$ \\
\hline Mitogen activated protein kinase 3 & Mapk3 & 50689 & 1.51 & 0.005 & $\begin{array}{l}\text { Inflammation-mediated chemokine and } \\
\text { cytokine }+ \text { B-cell activation }+ \text { Parkinson } \\
\text { disease +apoptosis }+ \text { integrin }+ \\
\text { leukotriene }\end{array}$ \\
\hline Muscle and microspikes RAS & Mras & 25482 & 3.72 & 0.000 & Integrin \\
\hline Mevalonate (diphospho) decarboxylase & Mvd & 81726 & 2.21 & 0.004 & Cholesterol biosynthesis \\
\hline $\begin{array}{l}\text { Nuclear factor of kappa light chain gene enhancer in } \\
\text { B-cells inhibitor, beta }\end{array}$ & Nfkbib & 81525 & 1.41 & 0.001 & Apoptosis + Toll-like receptor \\
\hline Nuclear receptor subfamily 1 , group D, member 1 & Nr1d1 & 252917 & 2.58 & 0.04 & Circadian clock system \\
\hline Platelet derived growth factor, alpha & Pdgfa & 25266 & 2.10 & 0.000 & Unclassified \\
\hline Pyridoxal (pyridoxine, vitamin B6) kinase & Pdxk & 83578 & 2.97 & 0.004 & Pyridoxal phosphate salvage \\
\hline Phospholipase C, gamma 2 & Plcg2 & 29337 & 0.59 & 0.000 & $\begin{array}{l}\text { Inflammation-mediated chemokine and } \\
\text { cytokine + B-cell activation + } \\
\text { angiogenesis + PDGF signaling + VEGF } \\
\text { signaling }\end{array}$ \\
\hline Phospholipase D1 & Pld 1 & 25096 & 1.50 & 0.003 & Angiogenesis + Ras \\
\hline $\begin{array}{l}\text { Pleckstrin homology domain containing, family G } \\
\text { (with RhoGef domain) member } 5\end{array}$ & Plekhg5 & 310999 & 0.52 & 0.004 & Cytoskeleton + Axon guidance \\
\hline Pancreatic polypeptide & Ppy & 24677 & 0.43 & 0.01 & Unclassified \\
\hline Presenilin 2 & Psen 2 & 81751 & 2.07 & 0.03 & Notch signaling + Alzheimer disease \\
\hline Proteaseome (prosome, macropain) 28 subunit, 3 & Psme3 & 287716 & 1.54 & 0.000 & Cell cycle \\
\hline Peptide YY (mapped) & Pyy & 287730 & 1.62 & 0.001 & Unclassified \\
\hline RAB11a, member RAS oncogene family & Rab11a & 81830 & 1.55 & 0.000 & Huntington disease \\
\hline RAB8B, member RAS oncogene family & Rab8b & 266688 & 1.42 & 0.000 & TGF-beta signaling \\
\hline RAP2B, member of RAS oncogene family & Rap2b & 170923 & 2.16 & 0.000 & Integrin \\
\hline Resistin-like gamma & Retnlg & 288135 & 3.6 & 0.006 & Unclassified \\
\hline Ras homolog gene family, member B & Rhob & 64373 & 1.56 & 0.002 & $\begin{array}{l}\text { Inflammation-mediated chemokine and } \\
\text { cytokine + angiogenesis + integrin + axon } \\
\text { guidance + Ras + cytoskeleton regulation } \\
\text { by RhoGTPase }\end{array}$ \\
\hline Ribosomal protein S6 kinase, polypeptide 2 & Rps6kb2 & 361696 & 1.44 & 0.001 & PDGF signaling + PI3Kinase \\
\hline Scavenger receptor class B, member 1 & Scarb1 & 25073 & 2.52 & 0.004 & Unclassified \\
\hline Secretogranin V & Scg5 & 25719 & 1.55 & 0.001 & Unclassified \\
\hline Monocarboxylate transporter & Slc16a3 & 80878 & 2.36 & 0.000 & Unclassified \\
\hline SMAD family member 6 & Smad6 & 367100 & 0.67 & 0.000 & TGF-beta signaling \\
\hline MAD homolog 7 (Drosophila) & Smad7 & 81516 & 0.66 & 0.001 & TGF-beta signaling \\
\hline Smoothened homolog (Drosophila) & Smo & 25273 & 2.69 & 0.005 & Hedgehog signaling \\
\hline Small nuclear ribonucleoprotein polypeptide A & Snrpa & 292729 & 1.83 & 0.006 & mRNA splicing \\
\hline Synaptotagmin 12 & Syt12 & 191595 & 0.31 & 0.003 & Unclassified \\
\hline Toll-like receptor 3 & Tlr3 & 364594 & 0.74 & 0.007 & Toll-like receptor \\
\hline Tumor necrosis factor receptor superfamily, member 1a & Tnfrsfla & 25625 & 1.64 & 0.000 & Apoptosis \\
\hline TOX high mobility group box family member 4 & Tox4 & 286990 & 1.93 & 0.006 & $\begin{array}{l}\text { Nucleoside, nucleotide and nucleic acid } \\
\text { metabolism }\end{array}$ \\
\hline Vascular endothelial growth factor A & Vegfa & 83785 & 2.82 & 0.000 & Angiogenesis + VEGF signaling \\
\hline $\begin{array}{l}\text { Tyrosine 3-monooxygenase/tryptophan } 5 \text {-mono- } \\
\text { oxygenase activation protein, gamma polypeptide }\end{array}$ & Ywhag & 56010 & 1.85 & 0.000 & FGF signaling + PI3Kinase \\
\hline
\end{tabular}

One gene did not amplify on the 96 -well LDA panel platforms and therefore only 93 of 94 test genes are reported in this table. The gene was Cga (Gene ID 116700), glycoprotein hormones, alpha subunit, with FC 0.390 and p value 0.02 . Two genes were used as controls and not listed in the table. All genes in this table are currently (July 2011) recognized as genes at the NCBI website. 


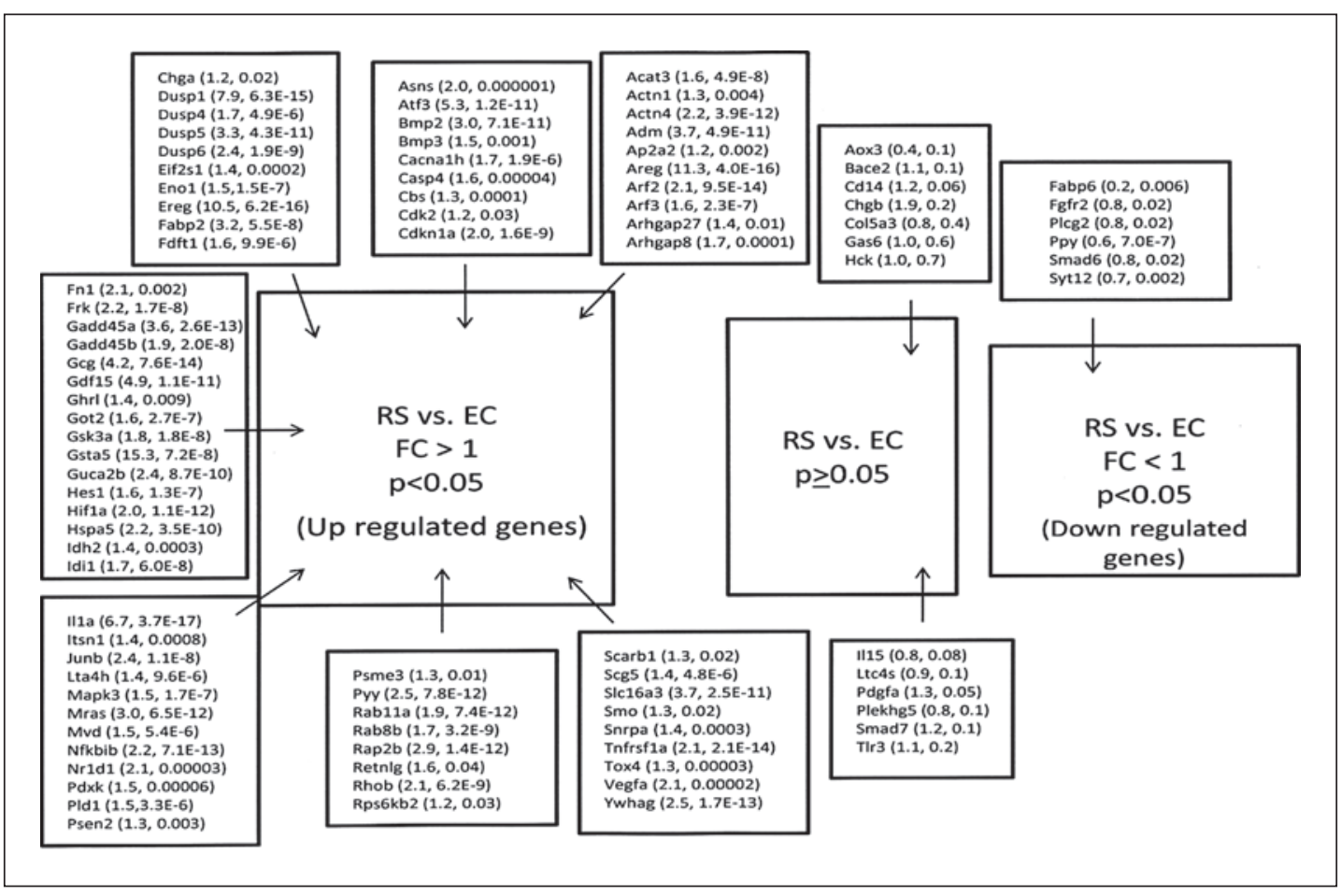

Fig. 2. Results of validation for the RS versus EC comparison. Genes are identified by their abbreviation, followed by FC and p value in parentheses, separated by a comma. Names of genes and their abbreviations are listed in table 3.

list contained genes significantly overrepresented in 44 pathways. One gene did not amplify in the TaqMan ${ }^{\circledR}$ custom arrays so we report on 93 genes from the custom arrays (fig. 2-4). For the RS versus EC comparison, there was validation of $86 \%$ of the genes as 80 out of 93 genes that had a significant difference in FC with the microarray showed a significant difference with the custom arrays. Chosen from the microarray were 74 genes with a FC $>1$ and low $\mathrm{p}$ values. Seventy-two of these genes were significant with the custom arrays. Of the 19 genes with a $\mathrm{FC}<1$ and low $\mathrm{p}$ values with the microarray, 8 were significant using qPCR. Two genes changed from a significant $\mathrm{FC}<1$ to significant with a FC $>1$. In figure 5 , RS versus $\mathrm{CC}$ is compared for similarities and differences in numbers of genes that were either upregulated, not different, or downregulated grouped according to four broad categories of function. A hierarchical cluster for the RS versus EC comparison is shown in figure 6. Neurotensin was analyzed separately by individual qPCR. From the microarray and PANTHER results, the FC for RS versus EC for neurotensin was 8 , the $p$ value $<0.0001$, and the pathway assignment was unclassified. The individual qPCR results for neurotensin for RS versus EC, $\mathrm{RS}$ versus $\mathrm{CC}$ and $\mathrm{CC}$ versus $\mathrm{EC}$ were: $\mathrm{FC}=4.59, \mathrm{p}<0.0001 ; \mathrm{FC}=4.17, \mathrm{p}<0.0001 ; \mathrm{FC}=1.1$, not significant, respectively. Thus, the microarray results were largely confirmed.

\section{Other Results}

At the end of this 4-week study period, the RS and EC groups had reduced abdominal fat pads and body weights compared to the CC group, but RS and EC were not statistically different (data not shown). This is in contrast to our previous observations where rats fed HAMS-RS2 for 12 weeks had a significantly lower abdominal fat than the rats fed the EC diet 


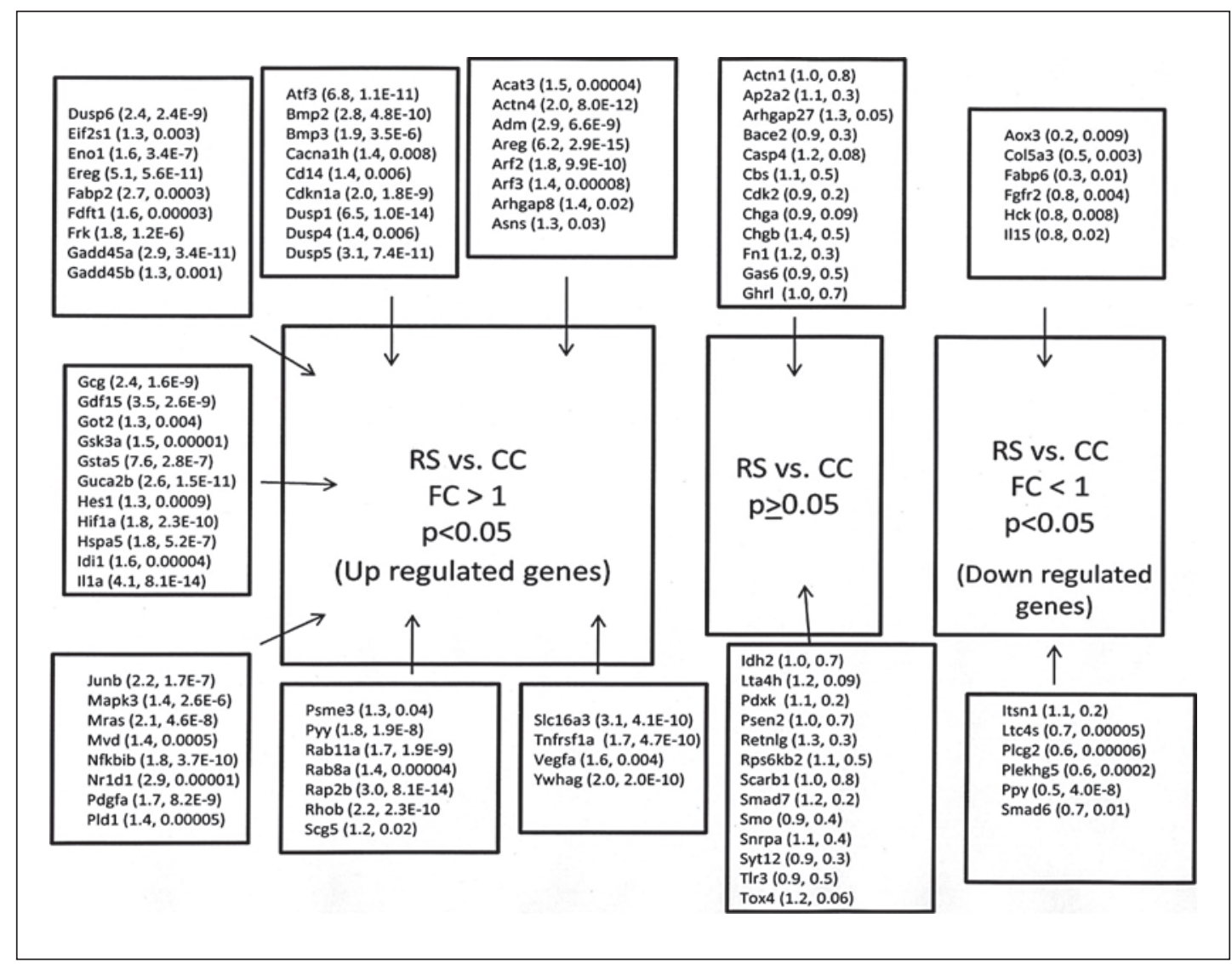

Fig. 3. Results of validation for the RS versus CC comparison. Genes are identified by their abbreviation, followed by FC and p value in parentheses, separated by a comma. Names of genes and their abbreviations are listed in table 3.

$[5,9,13]$. Thus, HAM-RS2 needs to be consumed for more than 4 weeks to elicit effects on adiposity when rodents are consuming an equal energy density diet and the difference between diets is the presence of higher levels of fermentable carbohydrate. The greater body weights and abdominal fat for CC rats were likely the result of their greater energy intake for CC compared to RS and EC (data not shown). Food intake (grams) was similar among groups, but the higher energy density of the CC diet resulted in greater energy intake. The RS groups had significantly greater $(\mathrm{p}<0.0001)$ full cecal weights than the $\mathrm{CC}$ and EC groups (RS 16.7, CC 2.6, and EC $3.2 \pm 0.9$ g pooled error), while the CC and EC groups were not different. $\mathrm{pH}$ of the cecal contents was much lower $(\mathrm{p}<0.0001)$ for RS than for CC and EC (RS 5.97, CC 8.14, and EC $8.49 \pm 0.05$ pooled error), and in the CC group cecal contents' $\mathrm{pH}$ was also significantly lower $(\mathrm{p}<0.0001)$ than in the EC group. Plasma total PYY (fig. 7a) and GLP-1 (fig. 7b) were increased for RS compared to CC and EC. The main goal of this microarray study was to examine the changes of gene expression profile in cecal cells with enhanced gut fermentation caused by dietary HAM-RS2. These results demonstrate that the fermentation of HAM-RS2 is established at the end of a 4-week period. 


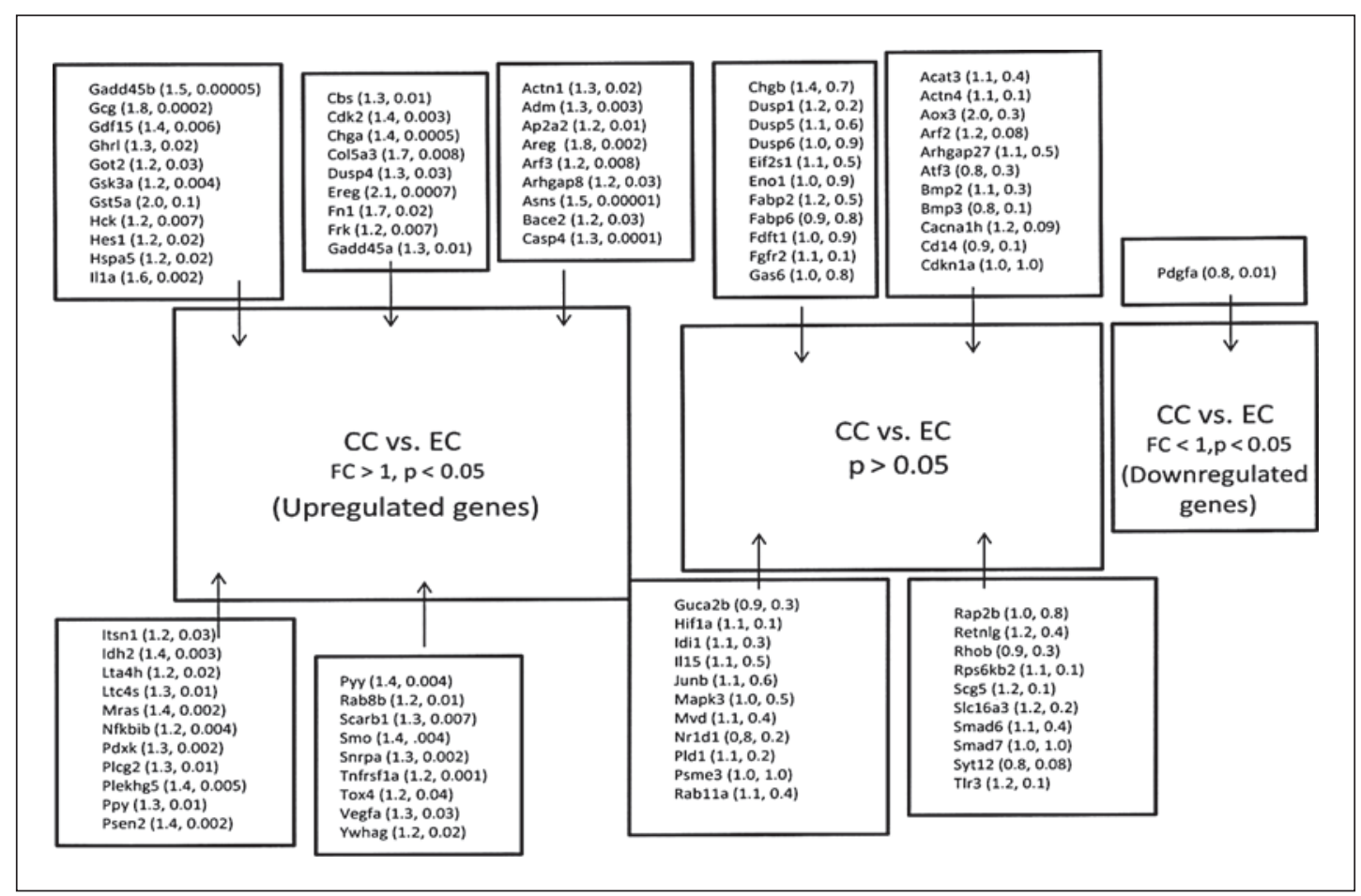

Fig. 4. Results of validation for the CC versus EC comparison. Genes are identified by their abbreviation, followed by FC and p value in parentheses, separated by a comma. Names of genes and their abbreviations are listed in table 3.

Fig. 5. Venn diagrams comparing RS and CC gene expression grouped according to four broad categories of function. The figure compares RS versus $\mathrm{CC}$ for similarities and differences in numbers of genes that were either upregulated (A, D, G, J), not different (B, E, H, K), or downregulated (C, F, I, L). The four broad categories are (1) growth and differentiation, regulators of cell cycle, and angiogenesis; (2) hormones and secretory proteins; (3) proinflammatory; and (4) transporters.

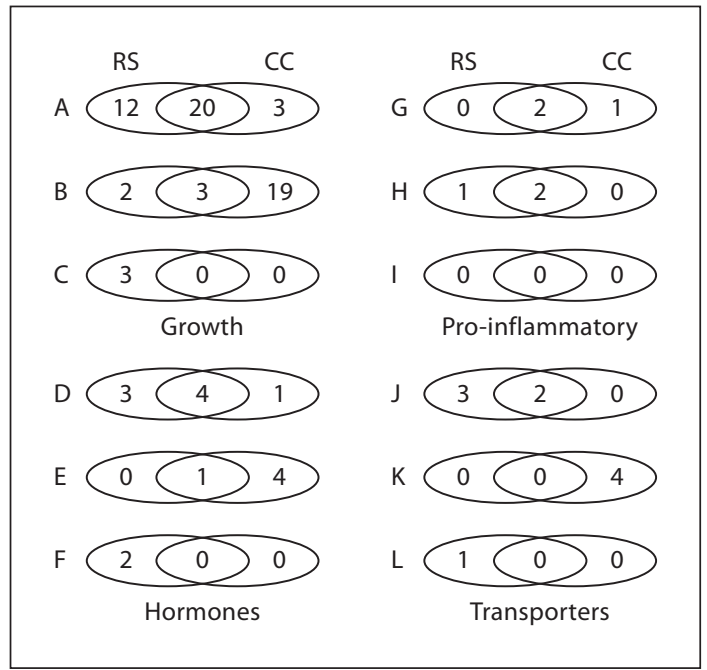

\section{Discussion}

The aim of the current study was to use microarray technology to analyze expression of many genes in a single experiment quickly and efficiently to understand the fundamental aspects of mechanisms related to colonic fermentation of HAM-RS2 diets that may improve health. Adding HAM-RS2 to a diet, replacing other starches, would lower the energy den- 


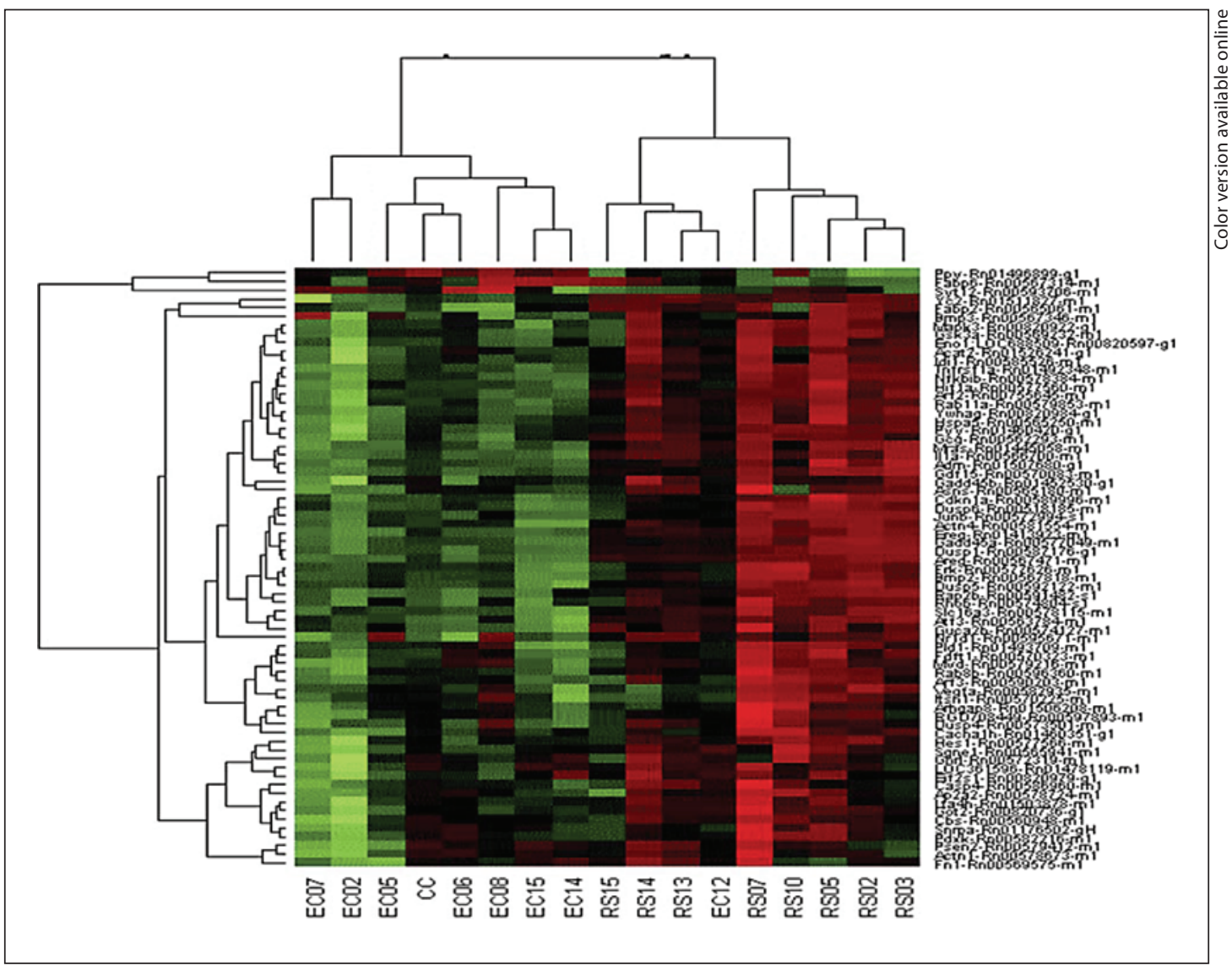

Fig. 6. Hierarchical cluster of the $\mathrm{Z}$ scores of the antilogs of the $2^{-\Delta \Delta C T}$ of RS versus EC from the TaqMan Custom Array panel results from the validation. The $\mathrm{Z}$ scores were determined by calculating the three groups' combined mean for each gene, and then individual differences of treatment replicates from the mean were divided by the standard deviation. This is one type of normalization for making gene-gene comparisons. Different genes are shown in each separate row. The columns are individual replicates of treatments and from left to right they are: EC7; EC2; EC5, mean of the CC group, EC6; EC8; EC15, EC14; RS15, RS14; RS13; EC12; RS7; RS10; RS5, RS2; RS3.

sity of the diet, which is an important contributor to causing change in the gene expression profile in the gut. We used an additional control group (EC group) to control for this confounding factor. Adding HAM-RS2 to a diet also increases the amount of fermentation in the large intestine, particularly the cecum. Fermentation of HAM-RS2 in the cecum has previously been shown to be associated with increased expression of cecal genes for PYY and proglucagon [5, 11], increased plasma levels of PYY and GLP-1 $[5,9,12]$, reduced abdominal fat $[5,8,9,13]$, and increased proopiomelanocortin in the arcuate nucleus of the hypothalamus [9]. Thus, in the current study, we used three treatment groups to assess the effects of simple energy dilution (CC vs. EC), fermentation with similar energy density of diets (RS vs. EC) or both energy density dilution and fermentation (RS vs. CC) on global gene expression of cells from the cecum of rats.

Fermentation of HAM-RS2 leads to an increase in short-chain fatty acids in the lumen of the cecum, which affects all cells on the cecal inner surface. Our cecal cell collection method, similar to that in a recent study [18], allowed us to examine a broad view of gene expression affected by HAM-RS2 fermentation. In a previous study, fermentation was confirmed 


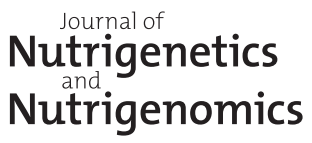

Fig. 7. a Plasma PYY levels (pg/100 $\mu \mathrm{l})$. b Plasma GLP-1 levels (pM). Bars with different superscripts are statistically different at $\mathrm{p}<0.0001$.

\begin{tabular}{l|l}
\hline J Nutrigenet Nutrigenomics 2012;5:26-44 \\
\hline $\begin{array}{l}\text { DOI: 10.1159/000335319 } \\
\text { Published online: April 20, 2012 }\end{array}$ & $\begin{array}{l}\text { @ } 2012 \text { S. Karger AG, Basel } \\
\text { www.karger.com/jnn }\end{array}$ \\
\hline
\end{tabular}

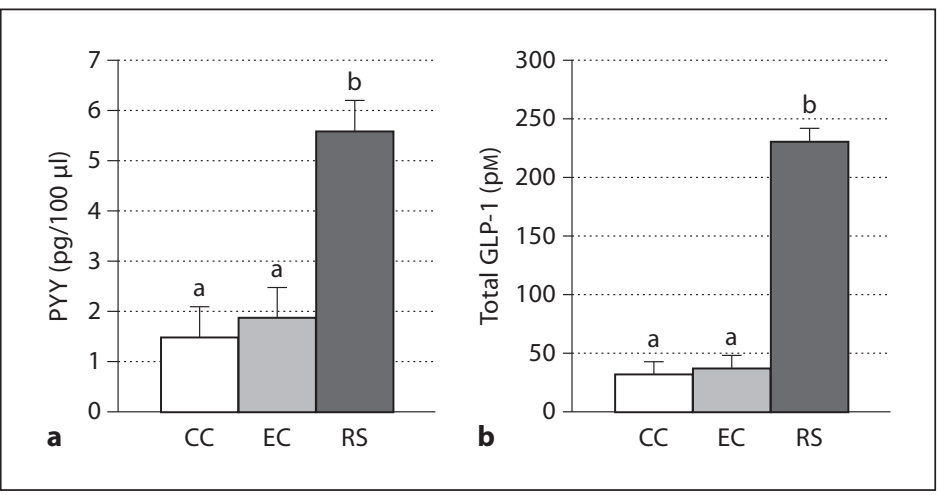

by measuring short-chain fatty acids in cecal contents after 1 week of feeding of HAM-RS2 [5]. After 4 weeks in the current study, HAM-RS2-fed rats had increased full cecal weights, decreased cecal contents' $\mathrm{pH}$, and increased plasma levels of PYY and GLP-1. All of these are well-known indicators of fermentation. Thus, the 4 -week study period allowed us to focus on changes in gene expression profile in cecal cells that resulted from fermentation of HAMRS2. Beginning the study with 8-week-old rats meant that the rats may be considered not quite adults. This may mean that some of the results in our studies may be due to adolescent growth. However, many of our studies use about this age as a starting age.

The results from the microarray indicated that about $38 \%$ of the genes of the rat genome $(10,000+$ out of approx. 27,000) were expressed above an acceptable level of noise (signal-tonoise ratio $\geq 3$ ) from the sampled cells (table 2). It was also validly hypothesized that the RS versus CC comparison should have the greatest number of gene differences because this comparison represents both a difference in energy density of the diet and greater fermentation with RS compared to CC. Hierarchical clusters of the microarray results (fig. 1) also demonstrated that there were global differences in the differential expression results of genes for RS compared to both the CC and EC groups.

Originally, the search for PANTHER pathways was for those that had a significant number of genes overrepresented and differentially expressed in an amount greater than by chance. Initially, the searches were restricted with Bonferroni adjustment. However, our next step was to focus on the RS versus EC comparison for validation of the microarray results. As a result, we expanded the number of PANTHER pathways by removing the Bonferroni adjustment. This was all dictated by our major goal, which was to examine the beneficial effects of fermentation beyond simple energy density dilution of the diet, and to broaden the scope for validation. Thirty-three of the 44 pathways were represented with the TaqMan ${ }^{\circledR}$ Custom Array panels for the validation focusing in on the RS versus EC comparison. Other genes included in the panels were for peptide hormones, growth and immune factors. The results from the validation demonstrate that our broadening was an effective strategy, as $86 \%$ of the genes from the microarray chosen for the panels remained significantly differentially expressed (fig. 2).

The general picture from the results of the validation of the microarray using the RS versus EC comparison is one of growth of the gut with appropriate signaling pathways for cell division and apoptosis. We previously showed increased thickness of the cecal mucosal layer with feeding of HAM-RS2 to rats (unpublished data: CC 3,979, EC 4,608; 19\% weight of diet as HAM-RS2 5,555 $\pm 172 \mu \mathrm{m}$ pooled error). Other researchers have reported increased colon proliferation in neonatal pigs fed fructooligosaccharide (FOS) [20], and this is considered healthy as there is increased surface area for absorption of nutrients [18]. Several 
genes were listed in PANTHER as part of the integrin pathway. These included Actn1 and Actn4, Fn1, Frk, Mapk3, Arf2 and Arf3 (see table 3 for gene abbreviations and names). Functions listed in PANTHER for this list of genes are in line with Rust et al. [21] who describe integrins as cell surface receptors that regulate many intracellular processes. These processes include 'growth, death (apoptosis), adhesion, migration, and invasion by activating several signaling pathways'. Integrins are also considered good targets for chemotherapeutic agents to treat cancer. Other genes also fit these functions. Mras appears to function in reorganization of the actin cytoskeleton [22]. Bmps are a group of growth factors also called cytokines that were originally discovered for induction of the formation of bone and cartilage, but they are now known to be morphogenetic factors important for tissue architecture throughout the body [23]. Dusp proteins respond to oxidative stress and also negatively regulate cell proliferation by inactivation of mitogen-activated protein kinase phosphatases [2426]. Areg mRNA was highly elevated in RS versus in $\mathrm{EC}$ rats $\left(\mathrm{FC}=11.3\right.$, $\mathrm{p}$ value $\left.=4 \times 10^{-16}\right)$, and the protein product of this gene is part of the epidermal growth factor (EGF) family and interacts with EGF and transforming growth factor-alpha (TGF- $\alpha$ ) to promote growth and regeneration of normal epithelial cells [27] and inhibit growth of certain aggressive cancer cell lines [28]. However, increased Areg is also associated with tumors [29]. Le Leu et al. [30] have reported that dietary RS promotes apoptosis of pre-cancerous cells, while not reducing normal cell proliferation. Thus, the data indicate that dietary RS supports normal healthy growth of the gut while likely preventing growth of tumors.

Similarly to simultaneous stimulation of growth factors and inhibitors of growth, there was an increase in the mRNA of a pro-inflammatory signal Illa [31]. Along with an increase in gene expression of Illa, there was increased expression for a regulator and promoter of the cell cycle, Cdk2 [32]. Apoptosis is required to turn off inflammation. Thus, there was also increased gene expression of Cdkn1a, the cyclin-dependent kinase inhibitor which promotes apoptosis of potentially inflammatory cells [33]. Several caspase proteins are involved in the activation of pro-inflammatory cytokines that function in innate immunity. However, for Casp4 no substrate has been identified and so its function remains unknown [34]. Tnfrsfla is a receptor for the TNF proteins [35]. Upon binding of TNF proteins to TNF receptors, one of three pathways can be stimulated based on cell type and conditions [36, 37]. TNF can be involved in either promoting or preventing apoptosis and stimulating the immune response. Thus, there was increased expression of genes for inflammation, cell proliferation and apoptosis.

Several other factors that had significantly increased mRNA for the RS versus EC comparison also support increased healthy growth of the gut. Eif2s1 is the alpha subunit of Eif that catalyzes the first regulated step of protein synthesis initiation, promoting the binding of the initiator tRNA to ribosomal subunits [38]. Ereg belongs to the EGF family of polypeptides and is involved in cell proliferation [39], but is also upregulated in cancer cell growth [40]. Several of the Gadd45 proteins promote apoptosis by activating mitogen-activated protein kinase kinase (MEKK/MTK1), which then increases mitogen-activated protein kinase kinase 4 (MKK4) and then phosphorylation of c-Jun N-terminal kinase [41]. In several types of cancer cells, nuclear factor kappa-light-chain-enhancer of activated B cells (NF- $\mathrm{B}$ ) increases the protein cellular myc, which represses gene expression of GADD $45 \alpha$ and $\gamma$. The result is the escape from programmed cell death [42]. Jun-B proto-oncogene mRNA was increased and this occurs under the control of TGF- $\beta$ [43] and is associated with cell proliferation and differentiation [44]. However, knockdown of Jun-B in wild-type murine fibroblasts did result in increased proliferation and tumorigenicity [45]. Rhob inhibits NF- $\kappa \mathrm{B}$ activity, which would then promote apoptosis of damaged cells [46]. Gdf15 is produced in response to injury and regulates [47] inflammation, cell survival, proliferation, and apoptosis in several types of injured tissues with varying disease processes. Additionally, Nfkbib 
mRNA was increased indicating the binding of NF- $\kappa \mathrm{B}$ and increased apoptosis as NF- $\mathrm{KB}$ is known to be an inhibitor of apoptosis and increased activity increases risk of cancer [41]. Psme3 (also known as PA28 $\gamma$ ) promotes an interaction between tumor suppressor p53 and murine double minute oncogene (MDM2) and this may be the mechanism by which Psme3 inhibits apoptosis and promotes cell cycle progression [48].

Additionally, mRNAs of several genes whose proteins regulate blood flow were increased. Hifla mRNA was increased; the protein is a subunit of the transcription factor Hif1. This transcription factor plays a role in inducing the transcription of genes whose proteins play a role in survival during hypoxia, which also induces Vegfa [49]. Vegfa mRNA was also increased; the protein product promotes increased blood vessel development [50]. At the same time, Adm mRNA was increased; translation of Adm mRNA results in a proadrenomedullin peptide that upon post-translational modification results in a peptide that promotes vasodilation and hypotension by inhibiting angiotensin II [51]. However, Adm protein is also elevated in patients with disorders of the cardiovascular system [51]. All of these conditions, excluding the cardiovascular disorders, are necessary for growth of tissue.

Atf3 gene expression was highly upregulated. When the protein product of this gene was discovered to be a transcription factor, it was assumed that it was an activating factor because the majority of transcription factor proteins are activating factors and very few repressors have been discovered [52]. However, it was later discovered that there are several different alternatively spliced isoforms. Atf 3 functions as a repression element by its binding to promoters of genes and stabilizing inhibitory co-factors. Another version of the protein, Atf $3 \Delta$ Zip, lacks the ability to bind to DNA as it lacks the leucine zipper domain. This version of the protein actually activates gene transcription as it appears to bind to inhibitory co-factors and prevent their interaction with gene promoter regions [52]. Hackl et al. [53] discuss that Atf3 is involved in 'the complex process of cellular stress response.' Moreover, under various conditions the protein can have tumor-suppressive or oncogenic effects. They reported that downregulation of Atf3 promoted colon cancer and that blocking the production of heat shock protein 90 increased Atf3 production [53]. Another recent publication reported that Atf3 can have positive or negative effects on proliferation and survival of adult T-cell leukemia cells depending on the conditions [54].

Genes for several detoxifying enzymes were upregulated in the RS versus EC comparison. Gsta5 represented this group in the validation. It appears that increased levels of expression of these genes represent sensitivity to noxious chemicals [55]. Compounds known to protect against chemical carcinogenesis, such as coumarins and phenolic antioxidants, are known to increase amounts of glutathione S-transferase enzymes.

Additionally, several fatty acid-binding proteins were upregulated in the RS versus EC comparison. Slc16a3 is also a monocarboxylate transporter 4 that transports lactate, pyruvate and the ketone bodies acetoacetate and $\beta$-hydroxybutyrate [56]. Fabp2, which binds long-chain fatty acids [57] was upregulated, but Fabp6, which appears to bind bile acids in the cytoplasm after sodium-dependent uptake by enterocytes by active transport [58] was downregulated by RS. Several other Slc16a transporter proteins were upregulated in the gene array but were not included in the validation. For example, Slc16a1, also called monocarboxylate transporter 1 , transports short-chain fatty acids into cells $[59,60]$.

Several other gene mRNAs that were identified by PANTHER as proteins that are components of metabolic pathways were increased in the RS versus EC comparison. Acat 3 combines cholesterol and fatty acids to form cholesterol esters in several tissues. Acat1 is ubiquitous, but Acat3 is limited to intestine and liver [61]. Currently at the NCBI website the Entrez Gene ID number from PANTHER for Acat2 discussed in Hori et al. [61] refers to Acat3. Idh2 is a mitochondrial $\mathrm{NADP}^{+}$-enzyme that catalyzes the third step in the citric acid cycle converting isocitrate to $\alpha$-ketoglutarate [62]. Asns produces asparagine from aspar- 
tate. Cbs is an enzyme catalyzing the reaction of serine plus homocysteine to cystathionine. Enol is an enzyme that catalyzes the conversion of 2-phosphoglycerate to phosphoenolpyruvate in glycolysis. Pdxk converts pyridoxal to pyridoxal phosphate. All of the proteins from these genes would be important for normal cellular metabolism and their function is commonly known.

Three peptide hormone mRNAs, Gcg, Pyy, and neurotensin (Nts), that were increased for RS versus EC in the microarray were also validated with the panels or separately (Nts) by individual qPCR. Plasma levels of GLP-1 and PYY were also measured in this study and were elevated for RS compared to either CC or EC groups. Our lab group has previously demonstrated in several studies that Gcg and Pyy gene expression and plasma peptide levels are increased with feeding of HAM-RS2 to rodents $[5,8,9,11,12]$. Thus, Gcg and Pyy were used as positive controls for the microarray and validation. Gcg is the glucagon gene that is also referred to as preproglucagon or proglucagon. The protein is produced in pancreatic $\alpha$ cells, brain and intestine and undergoes different post-translational modification depending on the tissue [63]. In the L-endocrine cells of the intestine the products are GLP-1, glucagon-like peptide 2 and oxyntomodulin. PYY is also produced by L-endocrine cells in the intestine. In the gut these peptides are associated with improved health. Nts is produced by NT cells in the intestine [64] and is also produced in neural cells throughout the body. In the gut, Nts is reported to control gut motility [65]. GLP-1 and PYY are involved in glucose control [66, 67] and energy metabolism [68-75].

For the most part, but with some exceptions, gene expression results for the validation were similar for the RS versus EC and RS versus CC comparisons. However, the CC versus EC comparison results from the validation were quite different from the results of the other two comparisons (fig. 2-4). This was expected as the differences between the CC and EC groups were lower energy density in the EC diet and a greater amount of cellulose. Clearly then, the greatest amount of gene expression was altered in RS versus EC compared to EC versus CC. Thus, increased fermentation in RS rats had a fairly similar response for many genes to rats fed the $\mathrm{CC}$ diet with a greater energy density diet. The numerical results are summarized with Venn-diagrams in figure 5; and specific similarities and differences between these two groups of rats can be determined using figures 2 and 3 . The differences in results between RS and CC groups further demonstrate that fermentation of RS impacted the cecal gene expression profile more than energy dilution in rats.

Previous reports of gene array and validation results with other sources of fermentable fibers, such as FOS and wheat bran, demonstrate some general similarity to the results from the currently reported study $[18,76]$. Chen et al. [18] reported greater amounts of changes in gene expression with FOS than with wheat bran, presumably because of higher rates of fermentation and short-chain fatty acid production. Wheat bran is considered to ferment more slowly than FOS and its fermentation is less complete than FOS. Chen et al. also speculate that different transit times can affect fermentation and gene expression results. RS is generally used in rodent diets in greater amounts than for similar studies with FOS. In the current study, the amount of HAM-RS2 used was an amount that promotes abdominal body fat loss in rodents ( $>25 \%$ of weight of diet) $[5,8,9,13]$. Unlike Chen et al. [18] who report FCs $>1.6$, Fukasawa et al. [76] report FCs $>1$. We also chose to report data as FCs lower than a prescribed number such as 1.5 because many of the relatively lower FCs for gene expression had extremely small $p$ values. Obviously, there is no difference in significance at $p<0.05$ and $\mathrm{p}<0.01$ as significance is set by convention at $\mathrm{p}<0.05$. However, the risk of a type 1 error is much lower for the latter $\mathrm{p}$ value. Small FCs for RS versus EC with a very small $p$ value may represent important treatment differences because of very low variation of the mean.

One major advantage of our current microarray and validation study is that we employed an energy dilution control. Energy dilution occurs when dietary fiber components 
replace starches or other carbohydrates in diet formulations. Fukasawa et al. [76] increased FOS at the expense of sucrose, resulting in two groups similar to our RS versus CC comparison as their FOS group would have a lower energy density than their control group. On the other hand, Chen et al. [18] controlled for dietary fiber, but not energy density as their control diet with $10 \%$ by weight of diet as cellulose had a lower energy density than their experimental diets with either FOS or wheat bran. However, this difference is relatively small with a maximum of a $7 \%$ difference in energy density as the total fiber in all diets is only $10 \%$ of the diet. In the current study, the CC diet is essentially an AIN-93 diet [15] and has greater energy density than the RS and EC diets. Based on an approximate calculation using the metabolizable energy density of $2.8 \mathrm{kcal} / \mathrm{g}$ for the Hi-maize ${ }^{\circledR}$ high-amylose cornstarch [10], $\sim 50 \%$ of the HAM-RS2 in our HAM-RS2 diet is fermented. What this means is the following: (1) Hi-maize ${ }^{\circledR}$ high-amylose cornstarch is $~ 56 \%$ HAM-RS2, (2) based on the amount of Hi-maize ${ }^{\circledR}$ added to the diet, $530.7 \mathrm{~g} / 1,000 \mathrm{~g}$ of diet, $\sim 297 \mathrm{~g}$ of HAM-RS2/1,000 g of diet were added, (3) $\sim 50 \%$ of the $297 \mathrm{~g}$ of HAM-RS2 is not fermented. Using this approximation and information, the HAM-RS2 diet has $\sim 11 \%$ more non-fermentable fiber than the EC diet, but the same energy density. This includes $50 \mathrm{~g}$ of cellulose $/ 1,000 \mathrm{~g}$ of diet and $\sim 50 \%$ of the 297 $\mathrm{g}$ of HAM-RS2/1,000 $\mathrm{g}$ of diet or $148.5 \mathrm{~g} / 1,000 \mathrm{~g}$ of diet. The EC diet had $177 \mathrm{~g}$ cellulose added/1,000 g of diet. Thus, in the current study, we controlled for dietary energy density, were close in non-fermentable fiber, and tested for fermentable fiber with the RS versus EC comparison.

In summary, a microarray and validation of the microarray were conducted with a total RNA extract from cecal cells in rats fed one of three treatment diets, RS, CC or EC. About 10,000 of $\sim 27,000$ genes were expressed for all three groups. The greatest number of significantly differentially expressed genes was observed with the RS versus CC comparison as this comparison measured both differences in energy density of the diet and fermentation effects. However, the focus of the validation was primarily on the RS versus EC comparison because the two treatment diets were equal in energy density and specific fermentation effects were tested. Genes chosen for the validation had higher FCs, lower p values and had to be inventoried by Applied Biosystems. The validation was 'successful' as $86 \%$ of the genes chosen from the microarray were confirmed as significantly differentially expressed.

Further, the results demonstrated that fermentation of HAM-RS2 altered expression of genes that would result in cell growth, proliferation and differentiation of the gut, as well as expression of genes involved in apoptosis and control of cell proliferation. Additionally, expression of several genes related to metabolic pathways and gut peptide hormones was altered, such as GLP-1 and PYY. Plasma levels for these hormones were also increased. GLP-1 and PYY can have effects throughout the body. Overall, the increased gene expressions observed appear to improve the structure and function of the GI tract, according their functions and supporting information in the literature. Because fermentation of dietary resistant starch changes the gene expression profile in cecal cells, the physiological relevance of these gene expression changes requires further investigation to explore the beneficial effects of HAM-RS2 beyond simple dietary energy dilution as a fiber.

\section{Acknowledgments}

This paper was approved for publication by the Director of Louisiana Agricultural Experiment Station as manuscript No. 2011-239-6315. This research was supported by grants from National Starch LLC and the LSU AgCenter Biotechnology Program. Amioca ${ }^{\circledR}$ and Hi-maize ${ }^{\circledR} 260$ were supplied as gifts by National Starch LLC, Bridgewater, N.J.

This project used Genomics core facilities that are supported in part by COBRE (NIH P20-RR021945) and NORC (NIH 1P30-DK072476) center grants from the National Institutes of Health. 


\section{Nutrigenetics Nutrigenomics}

\begin{tabular}{l|l}
\hline J Nutrigenet Nutrigenomics 2012;5:26-44 \\
\hline $\begin{array}{l}\text { DOI: 10.1159/000335319 } \\
\text { Published online: April 20, } 2012\end{array}$ & $\begin{array}{l}\text { @ 2012 S. Karger AG, Basel } \\
\text { www.karger.com/jnn }\end{array}$ \\
\hline
\end{tabular}

Keenan et al.: Microarray and High-Amylose Maize Resistant Starch

\section{References}

1 Brown IL: Applications and uses of resistant starch. J AOAC Int 2004;87:727-732.

2 Cassidy A, Bingham SA, Cummings JH: Starch intake and colorectal cancer risk: an international comparison. Br J Cancer 1994;69:937-942.

-3 de Deckere EA, Kloots WJ, van Amelsvoort JM: Resistant starch decreases serum total cholesterol and triacylglycerol concentrations in rats. J Nutr 1993;123:2142-2151.

4 Higgins JA: Resistant starch: metabolic effects and potential health benefits. J AOAC Int 2004;87:761-768.

5 Keenan MJ, Zhou J, McCutcheon KL, Raggio AM, Bateman HG, Todd E, Jones CK, Tulley RT, Melton S, Martin RJ, Hegsted M: Effects of resistant starch, a non-digestible fermentable fiber, on reducing body fat. Obesity (Silver Spring) 2006;14:1523-1534.

6 Robertson MD, Bickerton AS, Dennis AL, Vidal H, Frayn KN: Insulin-sensitizing effects of dietary resistant starch and effects on skeletal muscle and adipose tissue metabolism. Am J Clin Nutr 2005;82:559-567.

7 Robertson MD, Currie JM, Morgan LM, Jewell DP, Frayn KN: Prior short-term consumption of resistant starch enhances postprandial insulin sensitivity in healthy subjects. Diabetologia 2003;46:659-665.

-8 Shen L, Keenan MJ, Raggio A, Williams C, Martin RJ: Dietary-resistant starch improves maternal glycemic control in Goto-Kakazaki rat. Mol Nutr Food Res 2011;55:1499-1508.

9 Shen L, Keenan MJ, Martin RJ, Tulley RT, Raggio AM, McCutcheon KL, Zhou J: Dietary resistant starch increases hypothalamic POMC expression in rats. Obesity (Silver Spring) 2009;17:40-45.

$\checkmark 10$ Tulley RT, Appel MJ, Enos TG, Hegsted M, McCutcheon KL, Zhou J, Raggio AM, Jeffcoat R, Birkett A, Martin RJ, Keenan MJ: Comparative methodologies for measuring metabolizable energy of various types of resistant high amylose corn starch. J Agric Food Chem 2009;57:8474-8479.

11 Zhou J, Hegsted M, McCutcheon KL, Keenan MJ, Xi X, Raggio AM, Martin RJ: Peptide YY and proglucagon mRNA expression patterns and regulation in the gut. Obesity (Silver Spring) 2006;14:683-689.

-12 Zhou J, Martin RJ, Tulley RT, Raggio AM, McCutcheon KL, Shen L, Danna SC, Tripathy S, Hegsted M, Keenan MJ: Dietary resistant starch upregulates total GLP-1 and PYY in a sustained day-long manner through fermentation in rodents. Am J Physiol Endocrinol Metab 2008;295:E1160-E1166.

13 Zhou J, Martin RJ, Tulley RT, Raggio AM, Shen L, Lissy E, McCutcheon K, Keenan MJ: Failure to ferment dietary resistant starch in specific mouse models of obesity results in no body fat loss. J Agric Food Chem 2009;57:8844-8851. Sajilata MG, Singhai RS, Kulkarni PR: Resistant starch: a review. Compr Rev Food Sci Food Saf 2006;5:1-17.

14 Reeves PG, Nielsen FH, Fahey GC Jr: AIN-93 purified diets for laboratory rodents: final report of the American Institute of Nutrition ad hoc writing committee on the reformulation of the AIN-76A rodent diet. J Nutr 1993;123: 1939-1951.

16 Behall KM, Howe JC: Resistant starch as energy. J Am Coll Nutr 1996;15:248-254.

17 Englyst HN, Kingman SM, Hudson GJ, Cummings JH: Measurement of resistant starch in vitro and in vivo. Br J Nutr 1996;75:749-755.

18 Chen Q, Swist E, Beckstead J, Green J, Matias F, Roberts J, Qiao C, Raju J, Brooks SP, Scoggan KA: Dietary fructooligosaccharides and wheat bran elicit specific and dose-dependent gene expression profiles in the proximal colon epithelia of healthy Fischer 344 rats. J Nutr 2011;141:790-797.

19 Livak KJ, Schmittgen TD: Analysis of relative gene expression data using real-time quantitative PCR and the 2(-Delta Delta C(T)) Method. Methods 2001;25:402-408.

20 Howard MD, Gordon DT, Pace LW, Garleb KA, Kerley MS: Effects of dietary supplementation with fructooligosaccharides on colonic microbiota populations and epithelial cell proliferation in neonatal pigs. J Pediatr Gastroenterol Nutr 1995;21:297-303.

21 Rust WL, Carper SW, Plopper GE: The promise of integrins as effective targets for anticancer agents. J Biomed Biotechnol 2002;2:124-130.

22 Matsumoto K, Asano T, Endo T: Novel small GTPase M-Ras participates in reorganization of actin cytoskeleton. Oncogene 1997; 15:2409-2417.

23 Bleuming SA, He XC, Kodach LL, Hardwick JC, Koopman FA, Ten Kate FJ, van Deventer SJ, Hommes DW, Peppelenbosch MP, Offerhaus GJ, et al: Bone morphogenetic protein signaling suppresses tumorigenesis at gastric epithelial transition zones in mice. Cancer Res 2007;67:8149-8155.

24 Kim GS, Choi YK, Song SS, Kim WK, Han BH: MKP-1 contributes to oxidative stress-induced apoptosis via inactivation of ERK1/2 in SH-SY5Y cells. Biochem Biophys Res Commun 2005;338:1732-1738.

25 Vogt A, McDonald PR, Tamewitz A, Sikorski RP, Wipf P, Skoko JJ 3rd, Lazo JS: A cell-active inhibitor of mitogenactivated protein kinase phosphatases restores paclitaxel-induced apoptosis in dexamethasone-protected cancer cells. Mol Cancer Ther 2008;7:330-340.

26 Vogt A, Lazo JS: Discovery of protein kinase phosphatase inhibitors. Methods Mol Biol 2007;356:389-400.

27 Shao J SH: Amphiregulin promotes intestinal epithelial regeneration: roles of intestinal subepithelia myofibroblasts. Endocrinology 2010;151:3728-3737.

28 Plowman GD, Green JM, McDonald VL, Neubauer MG, Disteche CM, Todaro GJ, Shoyab M: The amphiregulin gene encodes a novel epidermal growth factor-related protein with tumor-inhibitory activity. Mol Cell Biol 1990;10:19691981. 


\section{Nutrigenetics Nutrigenomics}

\begin{tabular}{l|l}
\hline J Nutrigenet Nutrigenomics 2012;5:26-44 \\
\hline DOI: 10.1159/000335319 & $\begin{array}{l}\text { ○ } 2012 \text { S. Karger AG, Basel } \\
\text { www.karger.com/jnn }\end{array}$ \\
Published online: April 20, 2012 &
\end{tabular}

Keenan et al.: Microarray and High-Amylose Maize Resistant Starch

29 Billings SD, Southall MD, Li T, Cook PW, Baldridge L, Moores WB, Spandau DF, Foley JG, Travers JB: Amphiregulin overexpression results in rapidly growing keratinocytic tumors: an in vivo xenograft model of keratoacanthoma. Am J Pathol 2003; 163:2451-2458.

-30 Le Leu RK, Brown IL, Hu Y, Young GP: Effect of resistant starch on genotoxin-induced apoptosis, colonic epithelium, and lumenal contents in rats. Carcinogenesis 2003;24:1347-1352.

31 Dinarello CA: The interleukin-1 family: 10 years of discovery. FASEB J 1994;8:1314-1325.

-32 Chen S, Law CS, Gardner DG: Vitamin D-dependent suppression of endothelin-induced vascular smooth muscle cell proliferation through inhibition of CDK2 activity. J Steroid Biochem Mol Biol 2010;118:135-141.

-33 Rossi AG, Sawatzky DA, Walker A, Ward C, Sheldrake TA, Riley NA, Caldicott A, Martinez-Losa M, Walker TR, Duffin R, et al: Cyclin-dependent kinase inhibitors enhance the resolution of inflammation by promoting inflammatory cell apoptosis. Nat Med 2006;12:1056-1064.

34 Martinon F, Tschopp J: Inflammatory caspases and inflammasomes: master switches of inflammation. Cell Death Differ 2007;14:10-22.

-35 Aggarwal BB, Aiyer RA, Pennica D, Gray PW, Goeddel DV: Human tumour necrosis factors: structure and receptor interactions. Ciba Found Symp 1987;131:39-51.

Chen G, Goeddel DV: TNF-R1 signaling: a beautiful pathway. Science 2002;296:1634-1635.

Wajant H: Death receptors. Essays Biochem 2003;39:53-71.

Hershey JW: Translational control in mammalian cells. Annu Rev Biochem 1991;60:717-755.

Shirakata Y, Komurasaki T, Toyoda H, Hanakawa Y, Yamasaki K, Tokumaru S, Sayama K, Hashimoto K: Epiregulin, a novel member of the epidermal growth factor family, is an autocrine growth factor in normal human keratinocytes. J Biol Chem 2000;275:5748-5753.

40 Zhu Z KJ, Friess H, Wang L, Zimmerman A, Yarden Y, Buchler MW, Korc M: Epiregulin is up-regulated in pancreatic cancer and stimulates pancreatic cancer cell growth. Biochem Biophys Res Commun 2000;273:1019-1024.

-41 Zerbini LF, Libermann TA: Life and death in cancer. GADD45 alpha and gamma are critical regulators of NF-kappaB mediated escape from programmed cell death. Cell Cycle 2005;4:18-20.

42 Zerbini LF, Libermann TA: GADD45 deregulation in cancer: frequently methylated tumor suppressors and potential therapeutic targets. Clin Cancer Res 2005;11:6409-6413.

43 Li L, Hu JS, Olson EN: Different members of the jun proto-oncogene family exhibit distinct patterns of expression in response to type beta transforming growth factor. J Biol Chem 1990;265:1556-1562.

44 Wilkinson DG, Bhatt S, Ryseck RP, Bravo R: Tissue-specific expression of c-jun and junB during organogenesis in the mouse. Development 1989;106:465-471.

-45 Gurzov EN, Bakiri L, Alfaro JM, Wagner EF, Izquierdo M: Targeting c-Jun and JunB proteins as potential anticancer cell therapy. Oncogene 2008;27:641-652.

46 Fritz G, Kaina B: Ras-related GTPase Rhob represses NF-kappaB signaling. J Biol Chem 2001;276:3115-3122.

47 Zimmers TA, Jin X, Hsiao EC, McGrath SA, Esquela AF, Koniaris LG: Growth differentiation factor-15/macrophage inhibitory cytokine-1 induction after kidney and lung injury. Shock 2005;23:543-548.

$\checkmark 48$ Zhang Z, Zhang R: Proteasome activator PA28 gamma regulates p53 by enhancing its MDM2-mediated degradation. EMBO J 2008;27:852-864.

49 Lang KJ, Kappel A, Goodall GJ: Hypoxia-inducible factor-1alpha mRNA contains an internal ribosome entry site that allows efficient translation during normoxia and hypoxia. Mol Biol Cell 2002;13:1792-1801.

-50 Holmes K Roberts OL, Thomas AM, Cross MJ: Vascular endothelial growth factor receptor-2: structure, function, intracellular signalling and therapeutic inhibition. Cellular Signal 2007;19:2003-2012.

-51 Rossi F, Bertone C, Petricca S, Santiemma V: Adrenomedullin antagonizes angiotensin II-stimulated proliferation of human aortic smooth muscle cells. Peptides 2006;27:2935-2941.

52 Chen BP, Liang G, Whelan J, Hai T: ATF3 and ATF3 delta Zip. Transcriptional repression versus activation by alternatively spliced isoforms. J Biol Chem 1994;269:15819-15826.

-53 Hackl C, Lang SA, Moser C, Mori A, Fichtner-Feigl S, Hellerbrand C, Dietmeier W, Schlitt HJ, Geissler EK, Stoeltzing O: Activating transcription factor-3 (ATF3) functions as a tumor suppressor in colon cancer and is up-regulated upon heat-shock protein 90 (Hsp90) inhibition. BMC Cancer 2010;10:668.

54 Hagiya K, Yasunaga J, Satou Y, Ohshima K, Matsuoka M: ATF3; an HTLV-1 bZip factor binding protein, promotes proliferation of adult T-cell leukemia cells. Retrovirology 2011;8:19.

55 Pulford DJ, Hayes JD: Characterization of the rat glutathione S-transferase Yc2 subunit gene, GSTA5: identification of a putative antioxidant-responsive element in the 5'-flanking region of rat GSTA5 that may mediate chemoprotection against aflatoxin B1. Biochem J 1996;318:75-84.

56 Dimmer KS, Friedrich B, Lang F, Deitmer JW, Broer S: The low-affinity monocarboxylate transporter MCT4 is adapted to the export of lactate in highly glycolytic cells. Biochem J 2000;350:219-227.

57 Franchini GR, Curto LM, Caramelo JJ, Delfino JM: Dissection of a beta-barrel motif leads to a functional dimer: the case of the intestinal fatty acid binding protein. Protein Sci 2009;18:2592-2602.

-58 Bonne A, Gosele C, den Bieman M, Gillissen G, Kreitler T, Pravenec M, Kren V, van Lith H, van Zutphen B: Sequencing and chromosomal localization of Fabp6 and an intronless Fabp6 segment in the rat. Mol Biol Rep 2003;30:173176.

59 Hadjiagapiou C, Schmidt L, Dudeja PK, Layden TJ, Ramaswamy K: Mechanism(s) of butyrate transport in Caco-2 cells: role of monocarboxylate transporter 1. Am J Physiol Gastrointest Liver Physiol 2000;279:G775-G780. 


\section{Nutrigenetics \\ Nutrigenomics}

\begin{tabular}{l|l}
\hline J Nutrigenet Nutrigenomics 2012;5:26-44 \\
\hline DOl: 10.1159/000335319 & $\begin{array}{l}\text { @ } 2012 \text { S. Karger AG, Basel } \\
\text { www.karger.com/jnn }\end{array}$ \\
\hline Published online: April 20, 2012
\end{tabular}

Keenan et al.: Microarray and High-Amylose Maize Resistant Starch

-60 Saksena S, Dwivedi A, Gill RK, Singla A, Alrefai WA, Malakooti J, Ramaswamy K, Dudeja PK: PKC-dependent stimulation of the human MCT1 promoter involves transcription factor AP2. Am J Physiol Gastrointest Liver Physiol 2009; 296:G275-G283.

-61 Hori M, Satoh M, Furukawa K, Sakamoto Y, Hakamata H, Komohara Y, Takeya M, Sasaki Y, Miyazaki A, Horiuchi S: Acyl-coenzyme A: cholesterol acyltransferase-2 (ACAT-2) is responsible for elevated intestinal ACAT activity in diabetic rats. Arterioscler Thromb Vasc Biol 2004;24:1689-1695.

62 Reitman ZJ, Jin G, Karoly ED, Spasojevic I, Yang J, Kinzler KW, He Y, Bigner DD, Vogelstein B, Yan H: Profiling the effects of isocitrate dehydrogenase 1 and 2 mutations on the cellular metabolome. Proc Natl Acad Sci USA 2011;108: 3270-3275.

63 Kieffer TJ, Habener JF: The glucagon-like peptides. Endocr Rev 1999;20:876-913.

64 Kislauskis E, Bullock B, McNeil S, Dobner PR: The rat gene encoding neurotensin and neuromedin N. Structure, tissue-specific expression, and evolution of exon sequences. J Biol Chem 1988;263:4963-4968.

65 Degolier TF, Duke GE, Carraway RE: Neurotensin decreases pepsin output and gastrointestinal motility in chickens. Poult Sci 1997;76:1435-1439.

66 Boey D, Sainsbury A, Herzog H: The role of peptide YY in regulating glucose homeostasis. Peptides 2007;28:390-395

67 Lovshin JA, Drucker DJ: Incretin-based therapies for type 2 diabetes mellitus. Nat Rev Endocrinol 2009;5:262-269.

68 Boey D, Heilbronn L, Sainsbury A, Laybutt R, Kriketos A, Herzog H, Campbell LV: Low serum PYY is linked to insulin resistance in first-degree relatives of subjects with type 2 diabetes. Neuropeptides 2006;40:317-324.

69 Batterham RL, Cowley MA, Small CJ, Herzog H, Cohen MA, Dakin CL, Wren AM, Brynes AE, Low MJ, Ghatei MA, et al: Gut hormone PYY(3-36) physiologically inhibits food intake. Nature 2002;418:650-654.

70 Lee M, Wardlaw SL: The central melanocortin system and the regulation of energy balance. Front Biosci 2007;12: 3994-4010.

71 Ma X, Bruning J, Ashcroft FM: Glucagon-like peptide 1 stimulates hypothalamic proopiomelanocortin neurons. J Neurosci 2007;27:7125-7129.

72 Osaka T, Endo M, Yamakawa M, Inoue S: Energy expenditure by intravenous administration of glucagon-like peptide-1 mediated by the lower brainstem and sympathoadrenal system. Peptides 2005;26:1623-1631.

73 Pannacciulli N, Bunt JC, Koska J, Bogardus C, Krakoff J: Higher fasting plasma concentrations of glucagon-like peptide 1 are associated with higher resting energy expenditure and fat oxidation rates in humans. Am J Clin Nutr 2006; 84:556-560.

74 Usui D, Yamaguchi-Shima N, Okada S, Shimizu T, Wakiguchi H, Yokotani K: Selective activation of the sympathetic ganglia by centrally administered corticotropin-releasing factor in rats. Auton Neurosci 2009;146:111-114.

75 Adams SH, Lei C, Jodka CM, Nikoulina SE, Hoyt JA, Gedulin B, Mack CM, Kendall ES: PYY[3-36] administration decreases the respiratory quotient and reduces adiposity in diet-induced obese mice. J Nutr 2006;136:195-201.

76 Fukasawa T, Murashima K, Matsumoto I, Hosono A, Ohara H, Nojiri C, Koga J, Kubota H, Kanegae M, Kaminogawa $\mathrm{S}$, et al: Identification of marker genes for intestinal immunomodulating effect of a fructooligosaccharide by DNA microarray analysis. J Agric Food Chem 2007;55:3174-3179. 